\title{
Representations of Masculinities in John Michael McDonagh Satirical Film Text The Guard
}

\author{
José Díaz-Cuesta \\ University of La Rioja, Spain
}

Copyright (c) 2018 by José Díaz-Cuesta. This text may be archived and redistributed both in electronic form and in hard copy, provided that the author and journal are properly cited and no fee is charged for access.

\begin{abstract}
This article focuses on the ways in which masculinities are represented in John Michael McDonagh's film The Guard and how they relate to satire. Following Pat Kirkham and Janet Thumim's framework, four different so-called "masculinity sites" are considered in a textual analysis of the film. The first site, the body, is doubly explored: with his dignified and discreet star persona, the way Brendan Gleeson contributes to the construction of Sergeant Gerry Boyle's body is significant, as is the manner in which the physical bodies of the male characters are portrayed, with particular focus on Boyle. The second site, action, gives the audience the chance to see Boyle in a variety of situations which result in him acquiring a legendary status. In the realm of the third site, the external world, Boyle is heavily influenced by his relationship to the Garda. In the final site, the internal world, Boyle reveals himself to have the capacity to listen to and understand both a colleague's widow and his own terminally ill mother. The contrast between Boyle's arguably heroic attitude and the politically incorrect and racist language he employs to undermine people in power contributes to the film's elaborate construction of satire.
\end{abstract}

Key Words. Masculinities, Satire, The Guard, John Michael McDonagh, Textual Analysis.

Resumen. Este artículo se centra en las formas en las que la masculinidad ha sido representada en la película de John Michael McDonagh The Guard y cómo éstas se relacionan con la sátira. Siguiendo las teorías de Pat Kirkham y Janet Thumim, se han considerado los así llamados cuatro "sitios de la masculinidad" para el análisis textual de la película. El primer sitio, el cuerpo, se explora doblemente: a través de su persona como estrella de cine, digna y a la vez discreta, Brendan Gleeson contribuye a la construcción del cuerpo del sargento Gerry Boyle de manera significativa, pero también a través de la corporeidad con la que se representan los personajes masculinos, con particular atención a Boyle. El segundo lugar, la acción, proporciona a la audiencia la oportunidad de ver a Boyle en variedad de situaciones que le llevan a adquirir un estatus de leyenda. En el ámbito del tercer sitio, el mundo exterior, Boyle está muy influido por su relación con el cuerpo de policía o Garda. Con respecto al último sitio, el mundo interior, Boyle muestra tener la capacidad de escuchar y entender tanto a la viuda de un compañero como a su madre terminalmente enferma. El contraste entre la 
actitud supuestamente heroica de Boyle y el lenguaje políticamente incorrecto y racista que utiliza para desautorizar a aquellos con poder contribuye a la elaborada construcción satírica de la película.

Palabras clave. Masculinidades, sátira, The Guard, John Michael McDonagh, análisis textual.

\section{Introduction: Representations of Irish Masculinities within a Universal Approach}

Had it not been for John Michael McDonagh's statements about Irish films when promoting Calvary, practically no one would have considered The Guard as anything but an Irish film. Yet McDonagh uttered the following words in a video interview:

I'm not a big fan of Irish movies. I don't find them to be technically that accomplished and I don't find them that intelligent. I'm trying to get away from the description of the movie as an Irish film in a way. It's not an Irish film. It's just set in Ireland with lots of Irish characters ... When you're making a film, you're trying to convince the Irish audience, "No, it's not like all those terrible Irish movies you've seen before". (Associated Press)

Among the various reactions to McDonagh's criticism of Irish films, that of James Hickey, Chief Executive of the Irish Film Board, stands out. He focused on supporting Irish involvement in both films:

The IFB supported both films which are culturally Irish stories featuring Irish talent throughout, and is happy to have done so. The excellent work of Irish cast and crew has contributed to making "Calvary" and "The Guard" the high quality films they are, which have been seen by audiences in Ireland and all over the world. (O’Connor)

McDonagh was later forced to explain his comments:

The interview I gave to the Associated Press came about during the recent US press tour where I was intentionally trying to position Calvary for an international audience. I didn't want it to be perceived as a small, parochial, "Irish" film. I wanted it to be seen as a universal movie dealing with universal spiritual and philosophical issues. This intention on my part has been wilfully misrepresented by a small section of the Dublin media with an axe to grind. What has been most dispiriting to me, however, is the low-level bigotry that has reared its head in the fallout from the interview. I am an Irish citizen, a child of Irish parents, nearly all my friends and work associates are Irish, and yet because I was born in London I supposedly have no right to comment on Irish film. (Clarke; emphasis added)

Although the discussion dealt mainly with Calvary, frequent mention of The Guard makes discussion of its nationality equally topical. It was certainly made in Ireland, but John Michael McDonagh identifies himself as London Irish, rather than pure Irish and in an interview by James Mottram states: "I don't feel particularly British. I don't feel particularly Irish" (Mottram). Mottram writes that McDonagh "spent his summers in his mother's home, County Sligo" and is very familiar with Galway, where his parents moved in 1993. However, in personal conversations with Irish film experts who prefer to remain nameless, I discovered 
that some consider McDonagh's approach to Ireland to be that of an outsider, or at best that of someone who knew County Sligo only as a young vacationer. This may explain the use of stereotype in his films, yet it is also true that McDonagh sought to create a film with universal, rather than purely Irish appeal. Indeed, it is precisely his ability to convey the concepts of masculinity and satire in a way that is accessible universally which is of interest here.

Even if one does not consider McDonagh an Irishman, his film work nonetheless fits within the category of Irish Films. In the preface to his 1989 Directory of Irish and IrishRelated Films, Matthew Stevens includes "films with an Irish theme or content" as well as "films made in Ireland by Irish directors on Irish subjects" within his definition (Stevens). The Guard falls within the former category, regardless of his or anyone else's view on whether it fits within the second.

The Guard made a strong impression on me when I first saw it in the cinema, and so was an obvious choice when considering Irish films which combine displays of masculinities with the use of satire. My research question is: How are masculinities portrayed in this satirical film text? The method I have followed is an analytic-synthetic one derived from Pat Kirkham and Janet Thumin's work on the representation of masculinities in film, You Tarzan: Masculinities, Movies and Men (1993).

\section{A Note on Method}

Kirkham and Thumin's four-site deconstruction of masculinities in film is very similar to the four aspects Raewyn Connell explores in her book Masculinities, derived from interviews with Australian men about their bodies, daily experiences, relationships with other people, and desires. The introduction to You Tarzan refers to masculinities in film as a mixture of four "sites": the body, action, the external world, and the internal world. I analyse each of these separately.

Before proceeding with the analysis of the film, I must acknowledge Debbie Ging's book Men and Masculinities in Irish Cinema, which has also addressed the topic of masculinities in The Guard, but does not implement the four-site framework I use as a theoretical base.

Together with this framework there are two further concepts to bear in mind throughout this article: one is satire and the other political correctness, the key object of the satire in this film. I use the Oxford Dictionary definitions as my reference point for both terms:

satire

noun [mass noun]

the use of humour, irony, exaggeration, or ridicule to expose and criticize people's stupidity or vices, particularly in the context of contemporary politics and other topical issues: the crude satire seems to be directed at the fashionable protest singers of the time.

political correctness (also political correctitude)

noun [mass noun]

the avoidance of forms of expression or action that are perceived to exclude, marginalize, or insult groups of people who are socially disadvantaged or discriminated against: women like him for his civil rights stand and political correctness. (Oxford Dictionary of English) 
It is my contention that The Guard makes use of these tools (humour, irony, exaggeration, and ridicule) in its criticism of contemporary issues and, particularly, political correctness.

\section{The Body in The Guard}

This site combines two elements: the star persona of the actors who perform in a film and the way the actors' bodies are portrayed on screen. This site often requires a more comprehensive analysis than the other three due to its twofold structure.

Since its original publication by Richard Dyer in 1979 (with a more recent edition in 1998), Stars has established a paradigm for the analysis of stardom in film studies. Dyer describes a framework of mutual interdependence between stars as a social phenomenon, stars as images, and stars as signs. In each of the three cases, according to Dyer, "it is assumed that we are dealing with the stars in terms of their signification, not with them as real people" (2). When referring to the "semiotics of stars", Dyer explains the term as "their specific signification as realised in media texts (including films, but also newspaper stories, television programmes, advertisements, etc.)" (1). In my analysis, I differentiate between the audience experience of the film and television texts in which the actors have starred and the other media appearances which have contributed to the creation of their star persona.

For reasons of space, I focus mainly on Brendan Gleeson in his performance as Sergeant Gerry Boyle and, to a lesser extent, on his American opposite, Don Cheadle, as FBI agent Wendell Everett.

Gleeson was 34 years when he began his career in the film industry. Previously, he had been a teacher and a stage actor, first in Dublin (his native city) and later in England. In Richard Dyer's words, "Stardom is an image of the way stars live. For the most part, this generalised lifestyle is the assumed backdrop for the specific personality of the star and the details and events of her/his life" (35). Gleeson's late introduction to film may be the reason why there are few newspaper stories which focus on his life beyond his performances on the big screen. Gleeson nevertheless gives interviews, particularly when promoting specific films. In a Sunday Times interview from 2001, Gerry McCarthy says of him that:

You might expect a master of disguise to be lithe and shadowy, like a criminal from a Sherlock Holmes story. A blank, forgettable man with no distinguishing features, who can mould his appearance at will. You would not expect this: a burly, muscular figure with a big grin spread across his familiar features. A man who, by his own admission, is recognised wherever he goes in Ireland, and is beginning to have the same effect abroad.

Yet in his own way Brendan Gleeson is a master of disguise. He never plays the same type of role twice. He has neither the interest nor the attention span to get caught in that kind of rut.

McCarthy echoes Gleeson's own words when he declares "They can't typecast me". At the time of this interview, Gleeson had not yet acted in many major roles and seemed content. Nine years later, when interviewed by Ryan Gilbey for the Guardian, his approach to leading roles had evolved:

I think every character actor at some stage likes to carry a film. It can be extremely liberating to just come in for a scene or two and do your thing. But I find it frustrating if I'm just doing little bits here and there for too long. Sometimes I do stop and say, "OK, I'm gonna hold out now until I get something a bit more substantial that I can sink my teeth into". 
Another conclusion that can be drawn from these and other interviews is that Gleeson is protective of his private life, even when explicitly questioned on the subject. He is particularly discreet regarding his sons, despite the fact that they are now adults and two of them have followed their father into acting. For example, when asked in a 2017 television interview whether Gleeson embarrasses his children, the actor replied, "Yeah, I get up in the morning". He goes on to explain:

I think it's kind of your job, anyway, to embarrass your children, like you start off where they don't get your jokes and stuff like that and that's kind of charming and everything. Then they start to get them and that's even better. Then they think they're brilliant and that's even better. And then ... They think they're absolutely useless. You know, and that's when you start saying right ... this is the time to embarrass them ... Yeah, that's your job as a father I think. (The Late Late Show, episode aired 1 August 2017, https://www.youtube.com/watch?v=-SyqGzOvszY)

Gleeson's approach to his privacy can be summarised with the following quotation: "I don't want people poking around in my private stuff. They've no business in it. My work is what I give to people, that's my job, and that's where it stops" (IMDb). IMDb also includes the following quote in reference to his star status: "I don't maybe follow the normal star profile, and it's not something that I particularly want to embrace in terms of the publicity thing and wanting to be famous and known".

However, in 2012 he appeared with his four sons in the Irish television special Immaturity for Charity (a lowbrow comedy fundraiser), which consists of comedy sketches in aid of St Francis Hospice, Raheny and Blanchardstown, Dublin. The hospice "suffered five consecutive cuts in budget from the HSE and is facing a huge struggle to maintain its incredibly valuable service", according to the production's own website, immaturityforcharity.com. The five Gleesons had roles and Brendan Gleeson's son Domhnall co-wrote the sketches with Michael Moloney. The family is happy to be exposed to media attention for a good cause.

Gleeson demonstrates a measured approach in his commitment to causes, for example in his response to Ryan Tubridy regarding the Harvey Weinstein case:

It's not just Harvey Weinstein, it's all over the place where people are in powerful positions and it's the abuse of power as well ... I think there will be a sea change ... women are getting more power ... you don't want to just reproduce it by having women bullying another people around. (The Late Late Show, episode aired 1 August 2017, https://www.youtube.com/watch?v=7tLa1LvvoG4)

The types of role Gleeson has accepted in the past are also an aspect of his star persona as they become the main point of reference for an audience when they watch a new film in which he stars.

Gleeson's career began when Jim Sheridan gave him the small role of a quarryman in The Field (1990), a film with a rural Irish setting. Small parts, together with some TV movie appearances and short films, were assigned to him. I Went Down, in 1997, resulted in a "Best Actor" nomination at the Irish Films and Television Awards and, in retrospect, was good preparation for the mob environment of The Guard. Appearances in Mel Gibson's Braveheart and Neil Jordan's Michael Collins meant international recognition for Gleeson, although it was not until he played Martin Cahill in John Boorman's The General that he began to be taken seriously by the film industry on both sides of the Atlantic and his popularity rose. In his Sight \& Sound review of The Guard, Macnab writes that "It's heartening, too, to see 
Gleeson - so often consigned to character parts - in his best starring role since John Boorman's The General (1998)" (62). Beyond Braveheart, he has played small but interesting roles in several Hollywood films, including Steven Spielberg's A.I. Artificial Intelligence and Martin Scorsese's Gangs of New York.

Gleeson is 1.88 meters tall (six feet, two inches), making for an impressive presence in the flesh and, undoubtedly, on screen. Despite his stature, in 2009 he played Winston Churchill in a TV movie, Thaddeus O'Sullivan's Into the Storm. According to Rob Paul, who draws from a variety of sources, Churchill was only 1.68 meters tall (five feet, six and a half), and so in O'Sullivan's film, Gleeson depicts a Churchill quite literally larger than life.

Gleeson was born in 1955, and was 55 years old when he appeared in The Guard. His age is significant as he could be regarded as over the hill and overweight but in fact his body in sequences of swimming, shooting, and cavorting with prostitutes, would be at home in an action flick. As a point of reference, the average age of the actors (including Irish-born Pierce Brosnan) who have appeared as James Bond, the prototypical Anglo-Saxon cinematic action hero, is around 40 (Flint). Liam Neeson, who became an Irish film star before Gleeson did, was born in 1952 and has played the lead role in the action saga Taken. Fiftysomething may be the new fortysomething.

Gleeson's co-star Don Cheadle has developed his own star persona, including through receipt of the 2007 BET Humanitarian Award for his work supporting the people of Darfur and his selection by the World Summit of Nobel Laureates to receive the 2007 Summit Peace Award with George Clooney for "their efforts in favor of pacifying the tormented region of Darfur and for helping save lives" (Wald).

Cheadle is usually given supporting roles, and has shared the screen with Denzel Washington in Carl Franklin's Devil in a Blue Dress, with George Clooney and Brad Pitt in the more recent Ocean's Eleven films, and with John Travolta in Dominic Sena's Swordfish, to give just a few examples. He is often seen on television too. Since his first appearance on the widely known Fame (which meant his role as Henry Lee was watched by a broad international audience), one of his most acclaimed performances is the role of Sammy Davis $\mathrm{Jr}$ in the movie The Rat Pack. Law enforcement characters are not new to him: he has played Lt Col. James "Rhodey" Rhodes in Jon Favreau's Iron Man series and Lt Jimmy Pierce in the TV movie Fail Safe. It is important to mention Hotel Rwanda, where he was the lead in the role of Paul Rusesabagina, a Rwandan humanitarian who saved more than 1,000 people during the Rwandan genocide. This performance saw Cheadle nominated for Best Actor at the Golden Globes, the Oscars, the Screen Actors Guild, and Broadcast Film Critics awards (alongside the humanitarian awards mentioned above). This leading role may be the closest reference point for his role as an FBI agent in The Guard. As Sergeant Boyle reminds him often, Cheadle is an African American ('black' is the word Boyle uses), which contrasts with Gleeson's white or Caucasian Irishness. The contrast is even more evident in the Spanish poster of the film (Image 1), especially in its most simplified version (Image 2). 

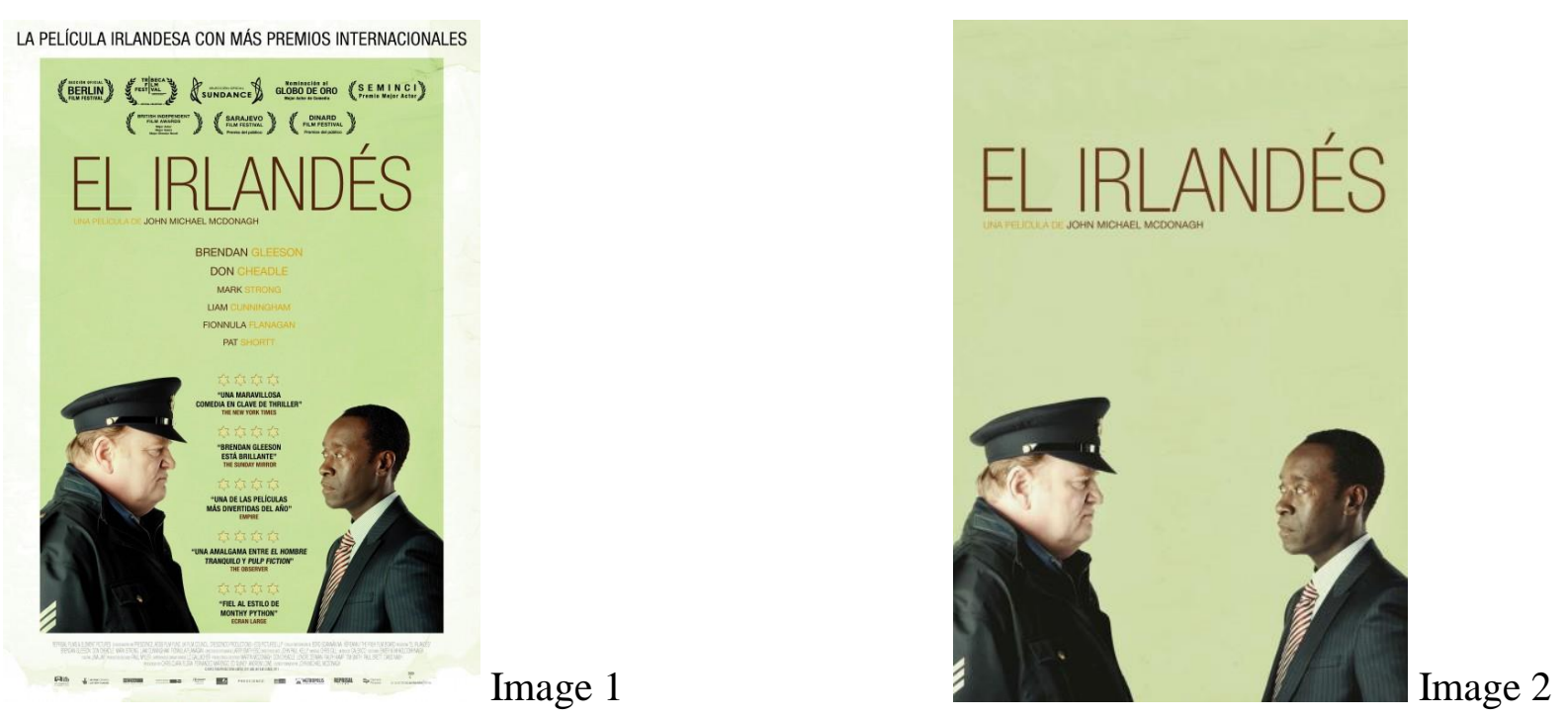

Even before they see the film, Spanish audiences are told that the film might include confrontation between these two men. They face one another in profile, Gleeson in his Garda uniform, Cheadle in his plain clothes suit, typical of an FBI agent. There is also the racial contrast, which is used by Boyle to make fun of Everett throughout the film, as discussed below.

Turning to the film itself, the first glimpse of Boyle's body is a close up of his face showing disdain. First appearances do matter in real life and on screen, and Gleeson's performance tells us much about the character's sardonic attitude to life. The next shot shows Sergeant Boyle's whole body half-kneeling, yet maintaining his upright position, as though he could not care less what had just happened as long as his Garda uniform stays clean.

After checking the quality of the drugs belonging to the man killed in the car accident, he is proleptically shown facing the sea, practically merging with it. He is "THE GUARD": the title over his head names and defines Boyle while Western-like music on the soundtrack sets the mood for the final confrontation of the film. The satirical tone that is retained through most scenes is established in this scene where the music contrasts with the setting of The Guard, which is so far removed from a typical Western landscape (though another west, that of Ireland, is being represented). The present-day location also adds to the contrast and enhances the satire which is directed as much towards the American buddy movies the director is attempting to parody as it is towards Westerns.

As if this Irish reference were not enough, Boyle next appears in his bedroom, with green walls, carpet, bedside table, and even a green telephone. White and green sheets, brownish-yellowish-orangish plaid: this is neither a shot of a bedroom nor simply a shot of a man, but rather an incarnation of the Irish flag.

Boyle's dress routine, which is also displayed as part of the DVD menu, includes not only his uniform, but also a pair of striped socks which signal early on how far this body will go in order to submit to some of the limitations of stereotype. In looking at himself in the mirror, Boyle is not only checking his looks, he is also testing whether the audience is capable of taking him seriously. For a moment, this dressing scene may remind the audience of Peter Cattaneo's The Full Monty, perhaps because it, too, recognizes that there is a lighter side to policemen. In fact, it is almost as if Boyle is in disguise during this scene. Yet the film emphasizes Boyle's dressing routine, which is repeated before the final action scene.

It is difficult to know what Boyle's plain clothes are. Although the audience has the chance to see him just before he puts on his uniform at the beginning of the film, the next time he is at home he is in his underwear. The audience may in fact wonder whether this is his normal state. This doubt is reinforced by his words: "I'll just slip into something a little less 
comfortable". That "something" turns out to be a silk gown, as though he were a mafia boss. Or James Bond, to choose a more cinematic comparison. He is like Sean Connery in Terence Young's Thunderball, or, without the silk, like Roger Moore in Guy Hamilton's Live and Let Die.

Yet the scene in which Boyle is most reminiscent of James Bond and which best displays his body's capabilities is that in which he emerges from the sea, leaving Everett open-mouthed and speechless. It is even more striking if this scene is observed as a parallel to the culmination of the James Bond beach scene of the very first Bond film, Terence Young's Dr No, and is reprised with a change in ethnicity 40 years later in Lee Tamahori's Die Another Day when Pierce Brosnan watches Halle Berry emerge in the place of Ursula Andress. Bond's binoculars are so powerful that they allow him to watch her in slow motion: they become the instrument of the gaze of both Bond and the spectator, and Berry is the object of that gaze. The next important step in this evolution occurs when Daniel Craig becomes the object of the camera's gaze - although he continues to stare at a woman, Solange, played by Caterina Murino. But the latest step in the evolution of the beach scene happens in The Guard. If Boyle is an Irish Bond figure here, is Everett in the place of Solange? McDonagh satirizes the Bond saga and offers his audience a more down-to-earth law enforcement agent.

To conclude this body section, an analysis of the last way in which Boyle's body is depicted in The Guard is pertinent in understanding the evolution of his bodily representation. Boyle's body's last intradiegetic appearance shows him turning his back on the mafia boss while he steps out of a room engulfed in flames on a boat that is about to explode. From the peaceful Irish policeman of the opening sequence he has transformed into an angel of justice surrounded by flames, all the while keeping his uniform (mostly) intact. Boyle goes missing while the audience watches the explosion and Everett's observation of it. Everett's silhouette against a burning background is immediately replaced by another shot of the back of his whole body which provides the audience with an opportunity to realize something is wrong with his right arm. When he turns round, his injuries sustained in the last shooting are visible; his is a body that needs care and healing while Boyle's has become a mystery.

\section{Action in The Guard}

Kirkham and Thumim understand the action site as corresponding to "various representations of the physical, including violence, competition, aggression, skill and endurance, in which these attributes are depicted in terms of the male body in action" (12). In The Guard, although there are several sequences which involve Boyle's body in action, a great part of the action is concentrated in the climatic shooting sequence near the end of the film. Another satirical moment sees Boyle's body perform an action that kills another person, that is, the scene where he faces down Liam O'Leary (David Wilmot), a member of the criminal gang who suffers from stress as a result of his lifestyle. O'Leary says he is on lithium, a medicine traditionally used to treat people with bipolar disorder. He does not show any sign of depression or mania, perhaps due to his medication. The conversation between criminal and policeman satirizes the typical action film confrontation where a hero seems about to be killed because in this case both characters display a deep understanding of each other, and are capable of effective sarcasm. However, it is their actions which are of most interest: Boyle insistently scratches at his crotch and when O'Leary asks him, "You alright there?" Boyle replies, “I think I might've picked up a little something I shouldn't have". O'Leary understands this to be a reference to some kind of venereal disease, but hindsight later shows that Boyle is distracting O'Leary to get hold of the gun he uses to kill him. The situation develops like a talk between two close friends, until Boyle draws the small gun from his 
crotch and shoots O'Leary. McDonagh chose a take in which the men mirror each other, the key difference being that Boyle is alert and active while O'Leary is distracted and passive. This sequence prepares the ground for what can be expected from Boyle in his final confrontation with the drug gang.

At the beginning of the final sequence Boyle arrives at the scene on his own, to be joined by Everett a few minutes later. Theirs is "a wary partnership that forms the heart of the film, even if it is an unbalanced one that throws all the good lines to the Irishman. (The script's main flaw is that Everett is so much less developed)" (Todd McCarthy 64). When they meet, Boyle passes the FBI agent an AK-47 rifle, commonly known as a "Kalashnikov". As Everett points out, its use may cause an international incident. In reality, its consequences could be even worse, due to the fact that Boyle got the weapon from the IRA, as the audience saw earlier in the film. In this way, the frame is shared, from left to right, by an American FBI agent, an IRA Kalashnikov, and an Irish guard. In passing the weapon to Everett, Boyle is getting him into more trouble than the American guesses. They are both now beyond the law and above it working to stop the criminal gang. Despite the means about to be used, Everett makes it very clear that what Boyle is attempting to do is "suicide". He uses a swear word before "suicide" both for emphasis and to express himself in a manner similar to Boyle's.

Just before the end of the conversation, after Everett has agreed to give cover fire to Boyle, the Irish sergeant asks whether being shot hurts. This leads to a comical exchange of opinions, but it cannot hide the fact that Boyle, the hero of the film, is afraid of suffering. However, when he is shot moments later he does not show much pain or distress; it is as if his body is momentarily out of reach of any kind of weakness, almost as though he is in possession of some kind of supernatural power.

The shooting turns into a celebration of this type of scene in other films. The Westernlike music that has been with us from the beginning of the film sets the tone for a confrontation that looks and, especially, sounds more like a sports game than a fight for survival. This feel is supported not only by the soundtrack, but also by some of the lines that appear in the dialogue. Perhaps what illustrates this point best is Cornell's reaction to Sheehy telling him to get out of there: "You're kidding me? This is better than fucking Christmas!" The parallelism cannot be overlooked: during the shooting scene there are henchmen transporting presents and there are many lights in the middle of the night (coming from the weapons being fired). Yet in this situation nobody is born unless someone might consider Boyle's disappearance as a form of rebirth, a transformation from a simple policeman/guard and a very imperfect man into a hero and a legend.

When Boyle shoots Cornell down, he does so from a kneeling position in order to secure a more precise target. The shot has deadly consequences for Cornell, who, before falling to the ground, also kneels down and has time to utter the words, "Good shot". The fighting dialogue resembles a tennis match with fair play and appreciation of the opponent's skill. To some extent, the film is self-consciously farcical using this combination of dialogue and action to implicitly remind the audience that what appears on screen is fiction.

A short moment before the boat explodes, Boyle has his final conversation with gang boss Francis Sheehy-Skeffington (Liam Cunningham). ${ }^{2}$ Despite having just declared that he knows how to die, Sheehy starts shouting after Boyle when he leaves him surrounded by flames. There are several shots of Sheehy shouting Boyle's name, but a middle shot taken from the ceiling of the room stands out: through it the audience watches him upside down as though the world of corruption and evil itself had been turned inside out. More importantly, his insistent repetition of that single word, "Boyle", has a double meaning: firstly, it represents the act of Sheehy calling him back, and secondly a definition of what will happen next or an instruction - with the heat Sergeant Boyle must "boil", turn from liquid (due to the amount of liquid in the human body and Boyle's preference for swimming in the sea) into 
vapour. ${ }^{3}$ This provides an alternative explanation to the mystery of Boyle's disappearance, alongside the obvious theories that he drowned or that his body has disintegrated in the explosion. If the explosion marked his end, such a transformation could also be linked to his surname and the change of state it implies. Rather than an act of heroism or suicide, Boyle's act becomes godlike - at the climax of the film he acquires an immaterial status which elevates him to the stature of a god-figure whom nobody sees but some feel is there. This idea is corroborated in the closing sequence by the faith of the photographer and the young boy that Boyle is alive. If Boyle is considered a hero, he only achieves this through being an antianti-hero, or, as Dawn Duncan argues, an ambiguous anti-hero:

In an age in which we use the term "hero" loosely when we simply mean we admire someone because of some particular talent, an age in which doubt trumps certainty, perhaps the reality is that we better understand the nature of the ambiguous anti-hero with all his or her complexities. They struggle and fail, but they attempt to grapple with this confusing life on their own terms. Even their morality is of their own making. (164)

When describing the kind of film he has made, the director says that he sees it "as an antiestablishment film that's working against all the buddy movies that came before" (qtd. in Lawrence 24). The choice of hero or protagonist contributes to such a description. It is interesting to note how much this film deviates from the interracial buddy film paradigm Melvin Donalson describes in his book Masculinity in the Interracial Buddy Film (10-11). Only two of the four areas framing the paradigm Donalson describes are present in The Guard: the first, which is the importance of the relationship between the interracial male characters, particularly significant as the film reaches its climax; and the third, which requires both males to be heterosexual (although Boyle does have a homosexual workmate in Garda Aidan McBride). But Boyle's and Everett's emotional, personal, and professional lives are rarely intertwined (third area), nor do they "achieve a union that acknowledges personal sharing and sacrifice for one another - personal demands that go beyond the conveniences of a friendship" (Donalson 10), which is the fourth area. However The Guard does fall within the category of "echo" buddy films, and McDonagh uses the power of this allusion to buddy films to reach a broader audience and subvert the genre at the same time:

Some ... films ... do not achieve the above four attributes for the entirety of ... [their duration]. Instead, traces of the interracial buddy pattern are used to achieve some other primary objective, allowing the film to merely "echo" or reflect the pattern. These "echo" films are not completely dismissible, because through their very existence, they make reference to the authentic pattern, drawing upon its narrative power. Further, the "echo" film exists as a marketing tool to lure audiences by promising the familiar pattern; this strategy demonstrates the extent of the popularity and profitability of the interracial buddy paradigm in the American cinematic tradition. (Donalson 10-11)

Through The Guard McDonagh transfers the power of that tradition from America to Europe, and, perhaps more importantly, from Hollywood to Ireland. The "echo" created in the film cannot be avoided by the audience, even if it registers at an unconscious level. Despite the way Boyle continuously makes fun of Everett, apparently because of his skin colour, Everett is the only person who helps the Garda in his eventual actions. As happens in most films of the subgenre, the issue of race is resolved by better understanding of the other's position, 
although Boyle seems to use it primarily as a way to provoke someone of a higher status than him, as I discuss further in the following section.

\section{The External World in The Guard}

For Kirkham and Thumim, the external world of male characters is composed of "filmic representations of the public interaction of male characters with each other and with the conventions and institutions against which they operate" (12). In the case of Boyle, the main institution against which he operates, apart from the local mafia, is the same An Garda Síochána police force for which he works. From the opening scenes after the car crash, Sergeant Boyle's lack of enthusiasm for his job is highlighted.

Another scene that demonstrates this tension occurs when Boyle, together with the newly arrived Guard Aidan McBride (Rory Keenan), is supposed to be working but is actually joining the dots of a puzzle for children. The phone rings and he answers with "Sergeant Gerry Boyle. Cop shop!" This apparent lack of interest in and respect for his own job and the institution he represents stands in clear contrast to his actions at the end of the film, analysed above. The person at the other end of the telephone line is Sheehy, who asks Boyle to repeat his name. Boyle answers in a routine tone, which gives no hint of the words to come: "Sergeant Gerry Boyle, the last of the independents". In the Irish context, "independents" refers to those who fought for independence. However, in the Gerry Boyle context, the term seems to apply only to himself, as he usually works alone. Only in the final scenes of the film does he ask for international backup in the shape of FBI agent Wendell Everett. Rather than independence, McDonagh, by means of Boyle, is "claiming the virtues of subversive individualism", according to Laura Canning (208).

The briefing where Everett provides the Gardai with details about the drug dealers who are linked to a recent murder is one of many examples of scenes where Boyle demonstrates that he is not only against the Garda he represents but also against a movement that is more difficult to tackle: political correctness. He interrupts Everett's explanation in order to ask: "I thought only black lads were drug dealers?" In case this question was not clear enough, and after Everett's polite, "I'm sorry, what?" he insists: "I thought only black lads were drug dealers. And Mexicans. What's it they call them? They have a word for them". Everett replies that there is a word for Boyle too. He is obviously referring to "racist". Eventually Everett does utter the word "racist", at which point Boyle declares: "I'm Irish sir. Racism's part of my culture". The other Gardai are amazed, surprised, and ashamed. The question that remains is whether Boyle is stating a fact or merely teasing his superiors. By articulating the belief that only black and Mexican people are drug dealers, the film satirizes a stereotype being perpetuated by American fictional films dealing with drug trafficking.

The fact that this film was so popular both in Ireland and internationally may indicate that, despite efforts towards political correctness, there are still ideas cannot be spoken aloud but lie deep in some people's hearts (and appear very publicly, for example, in tabloid newspapers). Racism is with us, and perhaps a good way - but of course not the only way - to approach and problematize the issue and attempt to eradicate it, is to address it within a satirical context like The Guard. There is a very thin line between satire and offence which, in my view, The Guard does not cross. Justin Chang in his Variety review comments that "McDonagh is an equal-opportunity mocker, and at times, the plot seems to serve as a mere pretext for him to squeeze in every possible jab at the various nationalities and constituencies represented onscreen" (32). One of those constituencies is perhaps those who pretend to be politically correct in public but show their racism in private. The director's own words may throw some light on this issue: 
Then at Tribeca [in New York] I was worried because there's a lot of racial sensitivity, and I wondered whether people were going to get the joke. But it played well there, too. It feels as though the audience is relieved that someone is finally making jokes on this topic. (qtd. in Lawrence 24)

However, one can hear on the streets of any town or city throughout the world thoughts expressed which may not, in fact, deviate much from Boyle's. What we as individuals within a society think could deviate even less. Satire and laughter exist when a truth - the fact that racism remains present in Western societies - is stated, no matter how inconvenient that truth may seem in a society that pretends to be politically correct. Only by accepting that racism exists and by fighting it can we overcome it. People laugh during this and many other moments of the film. Why do we laugh and not cry instead? We may be recognizing a part of each of us, the worst part of our inner selves which is hopefully less and less fed. Films like The Guard should serve the function of problematizing these kinds of issues: it may be easier to reach the minds and hearts of people of all ages, especially young people, if they are confronted with inconvenient truths and are capable of speaking their own truths in order to question themselves and move beyond their own prejudices. There are many films about crime and criminals - mainly dramatic films, a few of them comic - but few people criticize them for presenting a criminal mind as an example. In fact, without an element of evil, most critics will describe a film as lacking interest. Racism may be worse than criminal activity, in the sense that it is beyond a natural disposition: it functions as an ideology which allows its adherents to support exploitation and power, maintaining the status quo. Racism is still a serious problem, even in the most advanced societies, and cannot be overlooked. Films like The Guard contribute by throwing light on such issues and asking the audience to ponder what it is that makes them laugh.

A similar comment could be made about Boyle's relationships with women. When McBride's widow (Gabriela McBride, played by Katarina Cas) knocks on his door, Boyle takes her for a prostitute. Prostitution is yet another issue the film touches upon, albeit lightly, with Boyle failing to consider why these women are spending time with him, even when one of them has obviously been mistreated. Boyle is developed not as an example, but as a counter-example of how men should act. Yet he does care about Aoife O'Caroll (Dominique McElligot), the prostitute who has been hit and is part of Sheehy's attempt to blackmail him. In fact, Boyle eventually kills the men whom Sheehy says must have hit her in order to force her to do so. The conversation between the Guard, O'Caroll, and Sheehy happens in a café with typical American decor. The truth is that prostitution and sex trafficking are such successful businesses worldwide because, on the one hand, authorities give their tacit consent and, on the other, they are accepted by a portion of society whose dimensions are difficult to measure: at the very least by the clients of prostitutes and by those who profit from the business. Yet all kinds of abuse and degradation are often forcibly suffered by those who work in such roles. Once again, the role of films such as The Guard should be to assist audiences to consider these issues. The question remains as to whether The Guard is capable of making the audience reflect on at least some of these aspects. In my view, McDonagh's approach is too light here: he limits himself to recounting the events without problematizing them, as so often happens in real life.

\section{The Internal World in The Guard}

When analysing masculinities in a film text following Kirkham and Thumim's four sites, the internal world is usually the most difficult to uncover. They refer to it, in short, as "the experience and articulation of being, from the inside, as it were" (12). Boyle's internal world 
surfaces in the film during his conversations with two women: Gabriela McBride and his mother, Eileen (Fionnula Flanagan). These conversations could be considered to fall within the external world site, as they relate to institutions like marriage and the family but, given the topics involved and the way in which the scenes are shot, it seems more suitable to include them in an analysis of the internal world of Sergeant Gerry Boyle.

The conversation between Boyle and his colleague's widow looks and sounds more like a confession between a priest and a sinner than a conversation between a policeman and a victim. Both are sipping tea or coffee in a static two-shot take. The window behind them reflects their figures, especially McBride's, as if wanting to show them from all sides. The religious tone is underlined by the scarf Boyle is wearing around his neck, the position of his hands and the way he sits after she tells him her husband was gay. Boyle has asked for something personal and she delivers it to him. In line with the film's tendency towards satire, McBride begins an unnecessary explanation of what gay means, but Boyle guesses that theirs was a marriage of convenience: "I get the visa and he gets", she says, "Respectable", says Boyle. "Yes, respectable", she confirms. Once more, within the comedy this film delivers a nugget of reality in an attempt to lead the audience to consider the issue. But McDonagh seems to avoid the satirical approach he takes to race and gender in the way he tackles the issue of being gay. He links Aidan McBride's homosexuality to yet another theme: marriages of convenience. By accumulating too many references, too many critical issues, he loses the ability to deal with them all in depth. Many topics are touched upon throughout the film but with allusion and can only be fully uncovered in a second viewing. Homosexuality is, as mentioned above, treated less satirically than race and gender: the greater degree of respect both Boyle and McDonagh show towards this issue shapes the inner self of the sergeant as someone able to understand and empathize with the other.

Ging argues that Boyle is "stereotypically devoted to his mother" (122) as indeed he is. Their relationship is summarized by Doctor Oleywuko at the mother's hospice: "It's not what is on the outside that counts, it's what is on the inside". He is referring to the six to eight weeks she has before she dies, but the observation could be applied to the way mother and son interact. They share a controversial personality, as demonstrated when mother and son first meet in the film and she tells a fellow inmate not to make so much fuss about his mobility problems. This other side of Boyle should be understood within the stereotype of "the familiar dilemma between two ways of being an Irish man, the domestic and private, and the collective and political" (Foster 27).

Unsurprisingly, another meeting between mother and son takes place in a church, immediately after she has confessed to a priest. They talk about the use of drugs to alleviate her symptoms, which is yet another controversial and topical issue that is taboo in many countries. When they mention the word "cocaine", the priest she has confessed to can be seen in the background and visibly overhears. The conversation with Gabriela McBride has a confessional tone; this conversation with Eileen Boyle goes further to present the typical stereotypical - setting for a confession.

Boyle and his mother meet for the last time in a pub, fulfilling one of her last wishes, to listen to live music again. As well as their conversations on literature and on drugs (where they move beyond stereotypes), they also acknowledge Boyle's failure to be a "good son". She asks Boyle to pretend he never gave her a moment's grief, and it is significant that she asks for this pretence when she is so sick and most probably considering suicide (or euthanasia, yet another controversial subject). Once again, McDonagh points out the contradiction between what is said and what is thought and felt at the heart of finding a way to understand the world. It is only through the use of satire in the film that this contradiction is bearable. The film is not explicit, but it is very likely that Boyle has provided the drugs which 
his mother uses to kill herself in one of the ellipses of the story. Once again, serious themes are brought to the fore: euthanasia and/or suicide.

\section{Conclusions}

The representation of masculinities that has been analysed in this article focuses mainly on the portrayal of Sergeant Gerry Boyle by Brendon Gleeson in The Guard. Gleeson appears to be the perfect choice for the role of Boyle. His age, his physical appearance, and his previous roles all suit the character. Boyle is satirically portrayed as a representation of everything Irish, which has led to some negative reviews of the film, for example the following from The Irish Mail on Sunday, apropos of both The Guard and Calvary, McDonagh's immediately subsequent film:

McDonagh told AP that he didn't want his films to be viewed as "like all those terrible Irish movies you've seen before", but the problem is that that's exactly what they are ... IN FACT Calvary was even worse than The Guard, notwithstanding all the hard work from Brendan Gleeson ... In McDonagh's films, no Irish stereotype is left unturned. (Hourihane 25)

The film's use of satire compels us to compare Boyle to James Bond and the Bond girls who emerge from the sea in several 007 films (beginning with Ursula Andress in $\mathrm{Dr} N o$, continuing with Halle Berry in Die Another Day, and finishing with Daniel Craig as Bond himself in Casino Royale). That 007 moment takes place before the puzzled eyes of FBI agent Everett, whose body appears more ready for action than Boyle's, despite the fact that the American agent ends the film injured. Diane Negra has pointed out that re-masculinization can be a possible response to recession (226). This might be the case with Boyle, "the beset recession-impacted man whose anxieties are done away via his transformation into the remasculinized man" (Negra 235). Although Boyle seems transparent in his thoughts and behaviour, little is known about him or his past. There is no mention of his father, for example: perhaps his apparently trouble-free life is hiding this missing part of his character. The relationship with Everett is used by the director to play with the notion of the interracial buddy film, mainly by subverting what is expected of such a film.

Boyle is capable of killing in self-defence and also for revenge, which some may understand as a kind of justice. He sets his own limits, and is capable of acting beyond and above the law. At the end of the film it is uncertain whether he has died or simply vanished. Kevin Lally summarizes Boyle's evolution:

At first indifferent to the case, Boyle soon finds he has a personal stake in the outcome and the levels of local corruption that are coming to light. Gradually, he discovers his own personal code of honor, and a streak of valor that fuels him in the movie's tense, western-style climactic showdown at a pier. (79)

But the climactic action sequence may prevent the audience from recognizing and focusing on how the film lightly but bluntly addresses issues like racism, corruption, xenophobia, prostitution, and sex trafficking. Boyle serves as a counter-example on many of these themes (he declares himself racist, keeps to himself some of the drugs he finds when on duty, and has sex with prostitutes), but at the same time does worry about some, though not all, of the factors behind those situations.

When one turns to Boyle's inner world, one finds a man who is capable of understanding and listening to two women who are traumatized, one by the death of her 
husband, the other by her own approaching death from a terminal illness. The director reserves several Catholic confession-like moments for Boyle's conversations with these two women. At such moments Boyle is more a priest than a police officer, perhaps preparing Gleeson for his role in McDonagh's Calvary. Euthanasia, homosexuality, and marriages of convenience are some of the themes touched upon by Boyle and these women.

I have attempted to demonstrate that by means of satire, The Guard touches upon some controversial issues related to the representation of masculinities. In a conversation with both McBride's widow and Everett, Inspector Stanton says of Boyle, "He's not right in the head". The coda of the film revisits the moment when Everett wonders about his intelligence, but the reality of Boyle is more nuanced: he is a man who speaks inconvenient truths in a world that aims merely for political correctness when in reality more thorough analysis is required. Perhaps the film's key flaw is to touch upon so many societal issues without delving more deeply, yet in the end it is precisely this light touch, alongside the use of satire, which make The Guard accessible and the burden of such issues sustainable for its audience.

\section{Notes}

${ }^{1}$ The AK-47 or Kalashnikov is the weapon both policemen refer to, although, according to imfdb, what they are using is a Zastava M70B1, "the Yugoslavian variant of the Russian AK-47" (imfdb, "AK-47”). This article derives from the University of La Rioja's research project "El modo satírico, género y la constitución de identidades en los lenguajes visuales y literarios" (ref. APPI17/06). The research has also been sponsored by the University of La Rioja and the Autonomous Community of La Rioja through the V Plan Riojano de I+D+I, through which I was able to undertake a two-month research visit to the University of Toronto. Thanks are due to the Library of Trinity College, Dublin, for having allowed me access to their extensive catalogue during a two-week research visit. I am also grateful to Deborah Noble for her insightful comments on this article.

2 This unusual name, "Francis Sheehy-Skeffington", belonged to a famous pacifist who was executed by a British army officer in 1916 in an act that has been recognised as a war crime. He is supposed to have been the man upon whom James Joyce modelled his A Portrait of the Artist as a Young Man. McDonagh is playing with the subversion of roles in relation to this name by assigning it to a mafia boss.

${ }^{3}$ Earlier in the film, in conversation with Everett, Inspector Gerry Stanton (Gary Lydon) ponders the possibility of taking the expression "someone being liquidated" literally, as "actually being turned into liquid". Everett assures him it just means "killed", but Stanton's question opens the door to more literal explanations of what happens in the film.

\section{Works Cited}

Associated Press. "Gleeson on Ireland: 'There's a Rage"”. YouTube interview. 18 August 2014. 8 May 2018. https://www.youtube.com/watch?v=PkkfSQ5WQa4.

Canning, Laura. "“Not in front of the American": Place, Parochialism and Linguistic Play in John Michael McDonagh's The Guard (2011)". Estudios Irlandeses 7 (2012): 206208.

Chang, Justin. "The Guard". Variety 421.11 (2011): 12.

Clarke, Donald. "John Michael McDonagh Responds to Furore Concerning that Interview". The Irish Times. 19 September 2014. 8 May 2018. https://www.irishtimes.com/blogs/screenwriter/2014/09/19/john-michael-mcdonaghresponds-to-furore-concerning-that-interview/

Connell, Raewyn. Masculinities. Cambridge: Polity Press, 2001.

Donalson, Melvin. Masculinity in the Interracial Buddy Film. Jefferson, NC and London: McFarland \& Company, 2006.

Duncan, Dawn. Irish Myth, Lore and Legend on Film. Oxford: Peter Lang, 2013.

Dyer, Richard. Stars. London: British Film Institute, 1998. 
Flint, Hanna. "How Old is 007? Here's the Ages of Each James Bond in their First and Last Appearances". Metro. 27 September 2015. 8 November 2017. http://metro.co.uk/2015/09/27/how-old-is-007-heres-the-ages-of-each-james-bond-intheir-first-and-last-appearances-5409515/

Foster, John Wilson. "Corrigibly Plural? Masculinity in Life and Literature". Irish Masculinities: Reflections on Literature and Culture. Eds. Caroline Maggenis and Raymond Mullen. Dublin: Irish Academic Press, 2011. 13-34.

Gilbey, Ryan. "Brendan Gleeson: The Character Actor Who Steals the Show". Guardian. 18 March 2010. 8 March 2018. https://www.theguardian.com/film/2010/mar/18/brendangleeson-character-actor

Ging, Debbie. Men and Masculinities in Irish Cinema. New York: Palgrave Macmillan, 2013.

Hourihane, Ann Marie. "McDonagh's Films Are Irish (and Boring and Even Insulting)". The Irish Mail on Sunday. 21 September 2014. 25.

IMDb.

"Brendan

Gleeson". https://www.imdb.com/name/nm0322407/bio?ref_=nm_dyk_tm_sm\#trademark

imfdb (Internet Movie Firearms Database). "AK-47". 8 November 2017. http://www.imfdb.org/wiki/Zastava_M70\#Zastava_M70

Joyce, James. A Portrait of the Artist as a Young Man. New York: B.W. Huebsch, 1916.

Kirkham, Pat and Janet Thumin, eds. You Tarzan: Masculinity, Movies and Men. London: Lawrence and Wishart, 1993.

Lally, Kevin. "The Guard”. Film Journal International 114.7 (2011): 79.

Lawrence, Will. "The Most Arresting Cop Film of the Year?" Daily Telegraph. 17 June (2011): 24.

Macnab, Geoffrey. "The Guard”. Sight \& Sound 21.9 (2011): 61-62.

McCarthy, Gerry. "Brendan Gleeson Interview". The Sunday Times. 30 November 2001. 8 March 2018. https://www.thetimes.co.uk/article/brendan-gleeson-interviewOrng6n7220z

McCarthy, Todd. "The Guard". Hollywood Reporter 417.4 (2011): 64.

Mottram, James. "John Michael McDonagh: Stand Aside, Junior - Big Brother Coming Through". Independent. 6 August 2011. 8 November 2017. http://www.independent.co.uk/news/people/profiles/john-michael-mcdonagh-standaside-junior-ndash-big-brother-coming-through-2333058.html

Negra, Diane. "Adjusting Men and Abiding Mammies: Gendering the Recession in Ireland". Masculinity and Irish Popular Culture. Tiger's Tales. Eds. Conn Holohan and Tony Tracy. New York: Palgrave Macmillan, 2014. 223-237.

O’Connor, Amy. "Film Board Defends Irish Film in Wake of Controversial Comments by Calvary Director". Daily Edge. 15 September 2014. http://www.dailyedge.ie/johnmichael-mcdonagh-comments-irish-film-1671858-Sep2014/

Oxford Dictionary of English. Oxford: Oxford University Press, 2016.

Paul, Rob. "How Tall is Winston Churchill". Celebheights.com. 8 May 2018. https://www.celebheights.com/s/Winston-Churchill-49789.html

Stevens, Matthew. Directory of Irish and Irish-Related Films. Trowbridge: Flick Books, 1989.

Wald, Mary. "The Rome Summit of Nobel Prize Laureates". TheCommunity.com. 8 May 2018. https://thecommunity.com/project/george-clooney-and-don-cheadle-receivesummit-peace-award/

www.immaturityforcharity.com. Last accessed 8 March 2018. 
José Díaz-Cuesta is a permanent senior lecturer in Film Studies at the University of La Rioja (Spain). A graduate in English Studies from the University of Oviedo, he completed his Master of Arts in Film Studies at the University of Valladolid, and his doctorate at the University of La Rioja. His teaching and research interests are mainly in Anglo-American and Irish literature, and film and the relationships between both disciplines. He is particularly interested in the representation of masculinities and satire in film. Most of his research has focused on the works of Steven Spielberg. He has also written on Francis Ford Coppola, Ken Loach, Roger Donaldson and Bill Anderson. He also teaches English as a foreign language to undergraduate students and has lectured on contemporary Spanish film to foreign students. He has directed and produced several short films, mainly as part of some of the courses he is and has been teaching. He is currently pondering the possibility of making a low-budget feature film.

jose.diaz-cuesta@unirioja.es 